\title{
Some perspectives on the use of cheese as a food ingredient
}

\author{
John A. LUCEY* \\ Department of Food Science, University of Wisconsin-Madison, \\ 1605 Linden Drive, Madison, WI 53706, USA
}

\begin{abstract}
Over the past few decades, cheese has been growing in commercial importance in the food industry because of its use as an ingredient, including as a topping on pizza, filling in appetizers, slices on hamburgers, and sauces in pasta dishes. Traditionally, cheeses like Mozzarella, cheese powders, processed and imitation cheeses were the main ingredient cheeses but now there are a growing number of other cheese types being used as ingredients, e.g. in the US these include pizza type (i.e. cheese not meeting the standard of identity for Mozzarella), Hispanic and cream cheeses. For ingredient cheeses, such as Mozzarella, considerable research has been conducted on the impact of altering milk composition, manufacturing conditions and the type of starter cultures on the functional properties that are important for its use as an ingredient, e.g. slicing, shredding and melting properties. It is now recognized that insoluble calcium associated with the caseins in cheese plays a critical role in cheese texture, including melting properties. The total and insoluble calcium contents can be controlled by altering the critical $\mathrm{pH}$ values during manufacture, e.g. at coagulation or whey draining. Post-manufacture changes in the proportions of insoluble/soluble calcium are primarily responsible for most of the early changes in cheese texture and not proteolysis as was commonly believed until recently. End-users of cheese in various foods routinely demand consistent functionality over a long shelf-life and the cheese has to meet very specific performance targets, e.g. color and flow. Various approaches to modify the insoluble calcium content in cheese, studies on the performance of cream cheese as an ingredient and strategies to extend the acceptable performance window for cheese are described. A framework is presented that allows cheese texture and functional properties to be described in terms of specific molecular interactions of the caseins.
\end{abstract}

\section{functionality / insoluble calcium / rheology / texture}

摘要 - 干酪作为食品配料的前景。在过去几十年里, 干酪作为食品配料的使用量逐年 增加, 干酪主要用做比萨饼、开鲁食品、意大利面条的调味料、汉堡包等的配料。过去, Mozzarella 干酪、干酪粉、再制干酪和模拟干酪主要用作食品的配料, 但是现在, 许多其他 类型的干酪也用做食品配料, 如在美国广泛使用的 Pizza 型干酪 (这类手酪不执行 Mozzarella 干酪的标准)、西班牙干酪和奶油干酪。在这些干酪中, Mozzarella 干酪最具有代表性。关 于通过调整原料奶组成、改变加工条件和不同类型发酵剂对 Mozzarella 干酪功能性影响的 报道非常多, 而干酪的特性, 如切片性、破碎性和融化性等对加工食品的品质具有重要的影 响。研究证明, 干酪中与酪蛋白结合的不溶性钙含量影响干酪的质构和融化性。通过改变加 工过程中 (如凝乳或排乳清) 的 $\mathrm{pH}$ 可以控制总的和不溶性钙的含量。在加工后期不溶性/可 溶性钙比例的变化是导致干酪质构变化和蛋白不水解的主要原因。干酪在各种食品中使用 后的终端产品必须要考虑在货架期内干酪的功能性, 而且, 所用的干酪必须满足特定的要求, 如颜色和流动性。在干酪的研究中, 采用不同的方法来调整干酪中不溶性钲的含量, 如研究 改善奶油干酪性能使其适用于食品配料。新近的研究观点认为, 特定酪蛋白分子之间相互作 用决定了干酪的质构和功能性。

\section{功能性 / 不溶性钙 / 流变性 / 质构}

*Corresponding author (通讯作者): jalucey@facstaff.wisc.edu 
Résumé - Quelques perspectives sur l'utilisation du fromage en tant qu'ingrédient alimentaire. Au cours des dernières décennies, le fromage a pris une importance commerciale croissante dans l'industrie alimentaire du fait de son utilisation comme ingrédient, tel que garniture sur pizza ou dans les produits apéritifs, tranches sur hamburgers et sauces dans les plats de pâtes. Les fromages comme la Mozzarella, les poudres de fromages, les fromages fondus ou imitations ont été traditionnellement les principaux fromages ingrédients. Actuellement, un nombre croissant d'autres types de fromage sont utilisés comme ingrédients, comme par exemple aux États-Unis, les fromages de type pizza (c'est-à-dire des fromages non conformes aux normes pour l'appellation Mozzarella), des fromages hispaniques ou des Cream-cheeses. Pour les fromages ingrédients tels que la Mozzarella, une recherche considérable a été faite sur l'impact des modifications de la composition du lait, des conditions de fabrication et du type de levain sur les propriétés fonctionnelles importantes pour leur utilisation comme ingrédient, par exemple l'aptitude au tranchage, au broyage et à la fonte. Il est maintenant reconnu que le calcium insoluble associé aux caséines dans le fromage joue un rôle critique dans la texture du fromage et ses propriétés de fonte. Les teneurs en calcium total et insoluble peuvent être contrôlées en modifiant les valeurs de $\mathrm{pH}$ critique au cours de la fabrication, par exemple lors de la coagulation et de l'égouttage du lactosérum. Après la fabrication, ce sont les changements dans les proportions de calcium insoluble/calcium soluble qui sont principalement responsables de la plupart des premiers changements dans la texture du fromage, et non pas la protéolyse comme on le croyait jusqu'à récemment. Pour plusieurs applications, l'utilisateur final de fromage exige systématiquement des fonctionnalités constantes sur une longue durée de vie et le fromage doit répondre à des objectifs de performance très spécifiques, par exemple la couleur et l'écoulement. Différentes approches pour modifier la teneur en calcium insoluble dans le fromage, des études sur les performances du Cream-cheese comme ingrédient et les stratégies pour élargir la plage des performances acceptables du fromage sont décrites. Les grandes lignes permettant la description de la texture et des propriétés fonctionnelles des fromages sont présentées sous l'angle des interactions moléculaires spécifiques des caséines.

propriété fonctionnelle / calcium insoluble / rhéologie / texture

\section{INTRODUCTION}

Cheese is an extremely versatile food product that has a wide range of textures, flavors and end-uses. The texture and body of cheese varieties can range from soft to firm, smooth/creamy to curdy, brittle to long, mechanically open to closed, or from cheese with splits to round eyes. The physical properties of cheese are largely determined by the casein content, the type, number and strength of casein interactions, cheese composition and ripening reactions [35,53]. There have been several recent reviews on cheese texture and functionality $[18,19,27,53]$. Cheese has been used as an ingredient in various foods since the first recorded consumption of cheese itself, mainly to add flavor to bland foods. Nowadays, cheese is being used increasingly as an ingredient in a wide variety of prepared foods including appetizers, soups, sauces, casseroles, crackers, fillings in pastry and pies as well as the popular use of cheese as a topping on pizzas and as cheese slices on hamburgers and cold (sub)sandwiches. There have been several excellent reviews on the functionality required of cheese when used as a food ingredient $[23,25]$. Some of the uses of cheese as a food ingredient are listed in Table I along with some of the characteristics that are required from the cheese when used in these products.

In our previous reviews we have described some possible physico-chemical bases for textural properties [53] and the important role for calcium phosphate in modulating cheese functionality [39]. In the present article the focus will be on key performance attributes, both in the unmelted and melted state, for cheese when used as an ingredient. Some selected parameters that influence these performance attributes are discussed. End-users of cheese demand consistent 
Cheese as a food ingredient

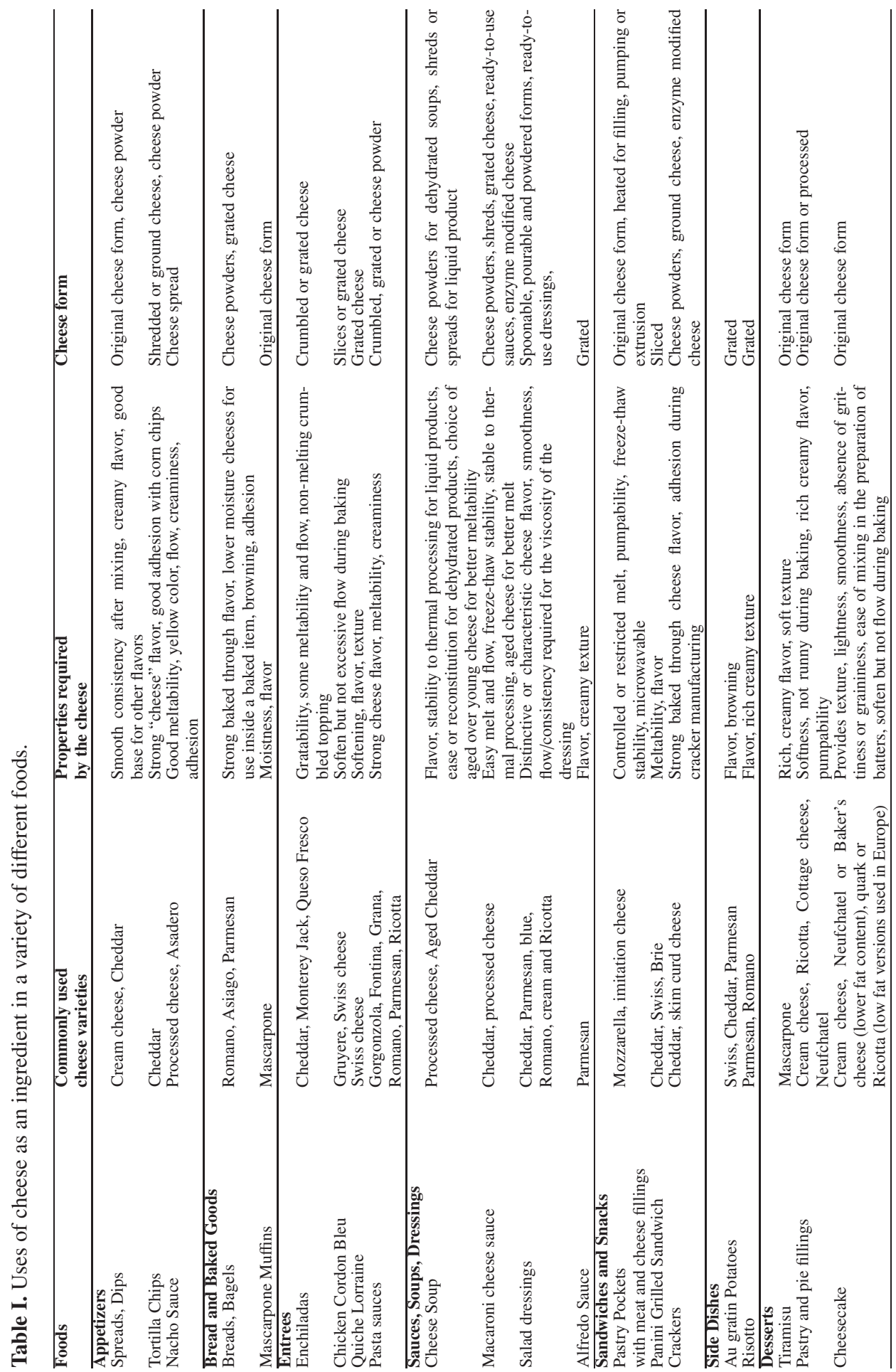


performance in their food products so cheese manufacturers have focussed their attention on various strategies to reduce changes in functionality during ripening. Cost is another critically important parameter as cheese is usually the most expensive ingredient in a food product. In the US, in addition to traditional ingredient cheeses, like Cheddar and low moisture part-skim Mozzarella, cream cheese is an important ingredient cheese. Cream cheese is used as an ingredient in cheese cakes and in spreads; some of the key textural attributes of this cheese type are also discussed.

\section{CHEESE FUNCTIONALITY}

There are a number of key parameters that are routinely manipulated to control the functionality of cheese. These parameters are often targeted in ingredient cheeses like Mozzarella [42-44, 73], but these parameters can be exploited as techniques to alter the functionality of other cheese varieties. Some general comments about these parameters are discussed below, see previous reviews on cheese functionality (listed previously) for a more extensive description of factors influencing cheese functionality.

\subsection{Parameters influencing cheese functionality}

\subsubsection{Composition}

Higher moisture cheeses are softer, smoother and more flowable than a similar (e.g. age, $\mathrm{pH}$, calcium content) cheese that has a lower moisture content. Low fat cheeses tend to be harder and less meltable than higher fat cheeses [17] unless corrective measures are taken by the cheese maker to alter these characteristics (e.g. by increasing the moisture content). Decreasing the fat content or reducing the calcium content of cheese results in a proportional increase in the protein and moisture contents. Cheeses with high protein content have an increased concentration of crosslinking material per unit area of the matrix compared to cheeses with lower protein contents, unless steps are taken to reduce protein-protein interactions (e.g. by reducing the ratio of insoluble calcium to protein or waiting for ripening to cause proteolysis). Cheeses with the same protein content but with a higher ratio of $\alpha_{\mathrm{s}}$-casein to $\beta$-casein have greater meltability [66].

Legal compositional limits often determine the moisture and fat contents of a particular cheese variety (e.g. the Code of Federal Regulations in the US). There are many ingredient cheeses that have their own specific compositions and they are classified as non-standard cheese (e.g. pizza cheese or process cheese product) since they are designed to have specific industrial functionality. Lowfat or nonfat cheeses are used by product developers in order to meet specific nutritional targets.

\subsection{2. $p H$ (acidity)}

Milk is a stable product because caseins have a net negative charge. Even if milk is gelled and made into a fresh cheese without significant acid development the curd is not able to stretch and melt due to excessive calcium phosphate crosslinking of caseins (e.g. Queso Fresco). Acidification removes calcium from within casein particles, i.e., colloidal calcium phosphate (CCP), and makes them more flexible, which is important for stretch [52, 53]. A critical amount of acidification is employed in cheeses, such as Mozzarella, so that it will have the desired melt, stretch and flow characteristics. If there is excessive acidification $(\mathrm{pH}<4.9$, e.g. Cream cheese, Feta) the curd loses its melt and stretch characteristics due to excessive: 
protein attraction (electrostatic and hydrophobic) between caseins [53]. The rate and extent of acid development during cheesemaking controls the calcium content of cheese and this rate can be changed by altering the $\mathrm{pH}$ at critical points during the process [52], the use of calcium chelating acids (e.g. citric acid) [41] and the use of a wash or whey dilution step to remove lactose/salts, e.g. Colby (a washed-type Cheddar cheese), Swiss (although not all Swiss cheesemakers use a wash or whey dilution step) or Gouda cheese.

\subsubsection{Temperature}

Temperature affects the association of casein molecules as they expand at low temperature due to the weakening of hydrophobic interactions. Low temperatures result in increased contact area between caseins and this causes the increased firmness [53]. Caseins contract with increasing temperature due to strengthening hydrophobic interactions so firmness decreases [53]. Heating results in a collapse of the cheese network and the pooling of free oil $[2,24]$. The marked variation in cheese texture with changing temperature is exploited to help shred cheese when it is cold so that it is firmer and easier to cut cleanly. The softening that occurs at high temperatures is widely exploited for the use of cheese as an ingredient in a range of baked foods. Over-ripe Camembert is runny even at refrigeration temperatures.

\subsubsection{Milk heat-treatment}

High heat treatments of milk (greater than pasteurization, or multiple pasteurizations) or other dairy ingredients (e.g. buttermilk [22]) causes a high level of whey protein denaturation. The denatured whey proteins interact with casein and result in a cheese with restricted melt and flow. The addition of acid to hot milk is used for the manufacture of several fresh cheeses (e.g. Ricotta, Queso Blanco). Acid-heat coagulated cheeses are non-melting cheese due to the formation of the covalent bonds between proteins (caseins and whey proteins) and these bonds hold the cheese matrix together even at high temperatures when changes to other interactions usually promote greater mobility of the network (which results in melt and flow).

\subsubsection{Homogenization}

Homogenization reduces the average fat globule size and greatly increases the fat surface area. Caseins and whey proteins are the main emulsifiers on this new interface. Homogenization of milk and cream is practised in the manufacture of blue cheese in order to increase lipolysis, which increases the concentration of free fatty acids, ketones and other flavor compounds. Homogenization of milk and cream is practised for Cream cheese, which is made from high fat milk (e.g. 12\%), and homogenization increases the consistency of this type of acidified products as the proteins on the newly created fat particles become an active part of the gel network. Homogenization also increases the moisture content of rennet-coagulated cheese by impairing the rearrangement and shrinkage of caseins that are responsible for syneresis (moisture loss) [37]. For natural cheeses, homogenization of milk and cream has sometimes been practised for lowfat Cheddar [57] and this can reduce the hardness and restrict the melt of these cheeses by interrupting the dense protein matrix. Homogenization is often practised for fresh Hispanic types of cheeses where restricted melt is required. Homogenization is used for cheeses "filled" with vegetable oils or where nutritionally valuable oils are added to cheese (e.g. oils rich in $\omega-3$ fatty acids). 
Recently, the impact of the milk fat globule size on cheese properties has been investigated [58, 59]. Microfiltration, with various membrane pore sizes, was used to produce milk fat fractions with small $(\sim 3 \mu \mathrm{m})$ or large $(\sim 6 \mu \mathrm{m})$ size globules. Small globules contain more short chain fatty acids [9]. Camembert cheese with small globules retained more moisture than cheese with larger globules [59]. Emmental cheese made with small fat globules had lower lipolysis and more intact fat globules whereas more destabilized fat was observed in cheese made with large globules. The functional properties of Emmental cheese made with small fat globules were improved with increased stretching, melting and lower extrusion force compared to cheese made with larger globules [58]. Smaller fat globules results in an increase in the number of fat globules and fat surface area compared to a cheese with the same fat content but larger average particle size. Presumably, the increased fat surface area due to the presence of small native fat globules would cause more disruption to the continuity of the casein matrix in cheese, which might be the reason for the observed textural differences in cheese made with small fat globules.

Changes in the structure of milk fat during the manufacture and ripening of Emmental cheese has been studied [50]. Fat globules were physically entrapped in the initial rennet coagulum but heating and pressing of curd grains caused aggregation and coalescence of fat globules. In ripened Emmental, three main forms of milk fat were identified: (i) small fat globules still covered by the native milk fat globule membrane; (ii) aggregates of partially disrupted fat globules; and (iii) free fat, resulting from the disruption of the milk fat globule membrane. In cheeses, like Camembert, that are subjected to less heating of the curd grains and little or no curd pressing, the size of the milk fat glob- ules in these cheeses are in the same range observed for the initial cheesemilk [49].

\subsubsection{Use of exopolysaccharide- producing (EPS) cultures}

Over the past 10 years there have been numerous studies on the impact of using EPS-producing cultures on the texture of low fat Mozzarella (e.g., [69]) or reduced fat Cheddar cheeses [3, 12]. The formation and structural properties of the various types of EPS produced by lactic acid bacteria have been reviewed [15, 84]. The production of EPS during cheesemaking results in cheeses with increased moisture content and altered textural properties. The increased moisture content may be due to EPS in some way interfering with the casein-casein rearrangements that are necessary during syneresis to remove moisture from curd grains. Another possible explanation is that these EPS physically trap moisture within the curd particles, as they are hydrocolloids, and thus, there may be less freely available water lost during cooking/pressing. The improved texture and melting properties that are reported in experiments with EPSproducing cultures are at least partly due to the increased moisture content in the EPS cheeses. The mechanism by which EPS influences the texture of dairy products like fermented milks and cheese is unclear $[32,83]$; some studies argue that the amount of EPS-produced is too low to have a functional impact, other suggest that there is a physical attachment of the EPS with the casein matrix [33] while others suggest that there is incompatibility between EPS and milk proteins (e.g. [80]). There are also concerns about the impact of EPS on whey processing and whey functionality; the use of some types of ropy strains for cheesemaking increased the viscosity of whey during the concentration step [70] whereas the EPS produced by 
some other strains may not have a large impact on the viscosity of whey $[12,70]$. The use of EPS cultures in cheesemaking has recently been reviewed [32].

\subsubsection{Use of transglutaminase}

Transglutaminase (TGase; EC 2.3.2.13) catalyses covalent intermolecular protein cross-linking through an acyl-transfer reaction, between the $\gamma$-carboxyamide group of a peptide-bound glutamine residue (acyl donor) and the primary amino group of an amine (acyl acceptor). The application of TGase in various types of dairy products has been reviewed [38]. In a system where caseins and whey proteins are available as substrates for TGase, such as milk, the caseins are preferentially cross-linked over native whey proteins [30]. Various approaches have been used for TGase treatment of cheese. Milk could be treated with TGase, held at some suitable temperatures (e.g. 20 to $40{ }^{\circ} \mathrm{C}$ ) for the reaction to occur and then a high heat treatment of milk or a cook step in the cheesemaking process used to inactivate the enzyme. However, one issue is TGase action results in the inhibition of rennet coagulation. Alternatively, cheese curd can be treated with TGase, some hold time allowed for the crosslinking to occur, and then the enzyme inactivated with heat; this approach has been used to improve the firmness of processed cheese [85]. Cream cheese with improved recovery of whey proteins and increased firmness has been reported after treatment with TGase [31]. Increased protein crosslinking by TGase could also reduce meltability.

\subsection{Unmelted cheese functionality and performance}

Unmelted cheese is subjected to a wide range of cutting and size reduction operations (e.g. shredding, slicing, grating, dicing, cubing, pureeing, crumbling, granulating, etc.) for food service or retail purposes. There are a number of functional attributes that are important for these operations:

\subsubsection{Firmness/hardness}

Cheese firmness increased by low moisture or low fat contents, and decreased by low insoluble calcium to protein content or low casein to fat ratio in cheesemilks. For Cheddar (and other medium to low moisture cheeses) firmness (at refrigeration temperature) does not change much during ageing in contrast to higher moisture cheeses (e.g. Mozzarella), which become softer and stickier with age. A low hardness and a medium to low yield stress value are required when cheese is used as a spreadable material.

\subsubsection{Brittleness (short texture)}

Short texture can be caused by low $\mathrm{pH}$ (e.g. crumbly Cheshire or Feta cheese), high salt, reduced calcium content, excessive proteolysis (e.g. very mature Cheddar cheese) or low moisture cheeses (e.g. hard grating Italian cheeses). The presence of high amounts of denatured whey proteins when combined with caseins in a cheese matrix can also make the cheese shorter. Cheeses with a surface rind (e.g. Gouda) become shorter and more brittle with age partly due to moisture loss. Ricotta has a short, particulate texture which is useful in pasta dishes where melt or stringiness would be undesirable.

\subsubsection{Machinability}

Machinability is a vague term for the ability for the cheese to be cut/sliced/shredded by machine (e.g. wires 
or high speed knifes). This attribute is influenced by cheese hardness (needs to be moderate to high), brittleness (should not be too "short" or it will be crumbly and will produce a lot of fines), and low adhesiveness (if the curd is too adhesive it will be stick to the metal). For pressuresensitive adhesives it has been reported that tack (sticking) will not occur when the storage modulus of the adhesive is greater than $10^{5} \mathrm{~Pa}$ but tack also depends on surface energies of the adhesive and adherend (in this situation the machine surface) [11]. Machinability is influenced by cheese composition, $\mathrm{pH}$, protein breakdown, and temperature of operation. In practice, machinability is controlled by the empirical selection of a suitable range for these parameters for an individual cheese variety, e.g., some cheeses may be suitable for shredding within a few days while others may be shredded for up to a few months. Shreddability is a broad term that is used to encompass many characteristics of shredded cheese including the ease of processing, the shape and integrity of the shreds, the propensity of shreds to mat or remain free-flowing, and the propensity to form fines during shredding [11]. Most size reduction operations are performed at room temperature although the cheese may be much colder; if cheeses are soft then they may be cooled to low temperatures to assist in increasing their firmness and thereby improve their machinability.

Some cheese types are difficult to slice or shred, e.g., Feta or Blue cheese, due to their short, crumbly texture. The cheese industry developed an alternative sizereduction approach of crumbles exploiting the short texture of these cheeses. Cheese crumbles are very suitable for sprinkling on salads and baked pizzas.

\subsection{Cooking and melting properties}

Melted cheese has found a vast number of applications, e.g. as a pizza top- ping, cheese slices on hamburgers, toasted sandwiches, fillings, layers in lasagna, and sauces. The end-users of cheese have very specific requirements for what kind of melt performance they want from their cheese. Cheese manufacturers can manipulate cheese performance to consistently meet these specifications. The functional properties of melted cheese are complex and we can distinguish at least seven important attributes namely flow, softening, shred identity, stretchability, tenting, blistering and browning.

\subsubsection{Flow (e.g. flow-off a pizza crust)}

Flow increases with age (due to protein breakdown/proteolysis, and ongoing loss of insoluble calcium from casein particles) and with an increase in the moisture or fat contents. There is very little flow in low $\mathrm{pH}(<4.9)$ cheeses, e.g. cottage or Feta. Flow is increased by a reduction in the calcium content. Cheeses with restricted flow can be achieved by high milk heat treatment, very high $\mathrm{pH}(>5.9)$ or very low values (i.e. $<4.9)$. Process cheese with restricted melt/flow can be achieved by the use of specific emulsifying salts (ES) (e.g. pyrophosphate) or the use of high temperatures and long hold times during curd cooking. Many Hispanic-style fresh cheeses, such as Panela, soften when heated but do not melt and flow due to the high pH (e.g. 6.4 to 6.5). Panela, and similar types of fresh cheeses, are widely used as a topping on tacos, chili and burritos. The use of acid to precipitate hot milk is exploited for a number of cheeses, e.g. Queso del Pais and Ricotta, and these cheeses soften but do not flow. A wide range of cheeses are manufactured with very different texture and flow properties. The dynamic rheological profiles of a number of different cheese varieties during heating have been reported [24,71]. 
It is sometimes suggested that changes in casein solvation or hydration is a key determinant of melt/flow but as discussed by Lucey et al. [53] cheese already has a very high water activity and there is very rapid exchange of water molecules from the interior of caseins to the bulk serum. Thus, water mobility does not appear to be a limiting factor in inhibiting melt. The observed age-related changes in expressible serum in some high moisture cheese, like Mozzarella, are caused by solubilisation of CCP and brine uptake into the cheese matrix.

\subsubsection{Softening during heating}

This happens in all cheeses, the extent depends on composition, age and $\mathrm{pH}$. Softening is caused by a reduction in the strength of the casein interactions with increasing temperature (as indicated by the reduction in the elastic moduli) and contraction of the network [24]. Thermal energy from heating promotes greater bond mobility (especially at temperatures $>35^{\circ} \mathrm{C}$, as indicated by the increase in the loss tangent parameter during the heating of most natural cheeses).

\subsubsection{Shred identity after heating}

This refers to individual shreds still visible after baking, which was caused by lack of softening and especially flow. Less common in aged cheeses as flow increases with age. Visible shreds can also be caused by excessive use of anticaking agents so these ingredients have very high melting points and if they completely coat the shreds this will keep the surface dry, preventing moisture or fat release and thus inhibit flow. Low moisture cheeses like Parmesan may exhibit shred identity after heating (often grated or finely ground Parmesan is used instead of shreds).

\subsubsection{Stretchability of curd during cheesemaking}

Curd stretches when sufficient calcium is lost from caseins during cheesemaking, e.g. $\mathrm{pH} \sim 5.2$ in cultured Mozzarella but occurs at $\mathrm{pH} \sim 5.6$ in direct acid Mozzarella [52]. The direct addition of acid to the cheese vat is more efficient approach to the removal of insoluble calcium than the cultured product where much of acid development occurs after whey drainage. The $\mathrm{pH}$ at which curd becomes suitable for stretching also depends on extent of demineralization (e.g. by preacidification with some acid helps to remove more CCP [41]), and fat and casein contents. Low fat or high casein (concentrated) milks require a lower $\mathrm{pH}$ at rennet addition or of the final cheese $\mathrm{pH}$ to get the curd to become suitable for stretching.

\subsubsection{Stretchability of cheese in its end-use application}

A lot of cheese is used as an ingredient on pizza. Stretchability is the ability of the melted cheese to form fibrous strands that elongate without breaking under tension during ripening [43]. Stretch "quality" is important, as many consumers do not want long "strings". Thus, the length, tension and type of stretch (strings, feathering or fibrous) are important quality attributes. Many young cheeses exhibit stretch (e.g. Cheddar) but during ripening the stretch quality decreases and the cheese may become stringy. During ageing of Mozzarella the length of stretch initially increases but after 3-4 weeks cheese may be "soupy" and the strands become short and weak [53].

\subsubsection{Tenting}

This term is usually used to refer to bulging of the cheese that may occur over a 
large area during baking due to the entrapment of water vapor. If this bulging occurs over a small area it is referred to as blistering. In reduced or low fat cheeses this process helps a surface "skin" to form; this skin may dry out and burn/brown during baking.

\subsubsection{Blistering and skinning}

This refers to small visual bubbles on the pizza surface. It is influenced by the textural (rheological properties of the surface) properties of cheese, which sometimes do not allow gas bubbles to escape from the surface (unlike a "soupy" product). Skinning is another surface defect that is often seen in nonfat cheese after baking or during cooling. Skinning describes the formation of a tough (dry) surface layer, which in nonfat cheese may seem like a clear plastic sheet.

\subsubsection{Browning}

During baking the color of some cheeses increases due to a Maillard reaction between reducing sugars (e.g. lactose) and proteins (especially amino acids). The color can range from light straw, to golden brown to black depending on the severity of the baking process, the concentration of reducing sugar and the type of oven used. Browning can be reduced by washing the curd as this reduces the lactose content and by selecting starter cultures so that all the residual sugars (including galactose) are metabolized. Other cheese manufacturing conditions can be varied to facilitate complete sugar fermentation, e.g. allowing more time at suitable temperatures to encourage continued bacterial fermentation prior to cooling or brining. Cheeses with slight browning or completely white are often requested by consumers. Aged cheeses contain amino acids that are sensitive to
Maillard reactions if some residual reducing sugars are still present. A reduction in the water activity of cheese promotes the Maillard reaction and contributes to the greater browning of cheeses like Parmesan (that occurs even at low temperatures).

In some types of cheese (e.g. Parmesan) there may be little or no residual sugars after a short aging period and yet these cheeses can in some situations undergo browning. Some types of lactobacilli have been shown to be able to produce various carbonyl compounds, e.g. $\alpha$-dicarbonyls [72], which are more reactive compounds than sugars for Maillard-induced reactions [79]. Lactobacilli species and strains vary greatly in their abilities to produce $\alpha$-dicarbonyls [7]. Thus, browning in some aged cheeses may be due to the metabolism of nonstarter lactic acid bacteria, like lactobacilli, and some type of favourable environmental conditions (e.g., $\mathrm{A}_{w}$, redox) for the Maillard reaction.

Hexose oxidase (EC1.1.3.5) has been used to reduce browning of cheese shreds when they are used in baking applications, e.g. on pizza [78]. Hexose oxidase oxidizes the reducing groups on sugars like glucose, lactose and galactose preventing their involvement in Maillard reactions. Oxygen is required for this oxidation reaction so an aerobic environment is needed. This treatment is done after cheese manufacture otherwise this reaction could inhibit bacterial fermentation of lactose.

\subsubsection{Free oil formation}

This is the tendency of free oil to separate from the melted cheese and form oil pockets, particularly at the cheese surface. Excessive oiling-off leads to a greasy, shiny surface. Free oil increases with age of cheese due to ongoing proteolysis. High salt levels have been reported to reduce free oil formation in Mozzarella 
cheese [14]. Some types of nonstarter cultures may metabolize glycoproteins in the milkfat globule membrane as a carbohydrate source [1] and it is possible that the metabolism of membrane components may weaken its integrity. Free oil may be beneficial in helping to control browning and blister formation [75]. Process cheese has very little free oil due to emulsification of fat by caseins during the heating and shearing that is used in the cooking process. Little free oil is released in cheese made from homogenized milk [74]. Treatment of milk for Mozzarella cheesemaking with phospholipase has been reported to reduce fat losses in the cooker stretcher and result in cheese with less free oil formation during ripening [67]. Lilbaek et al. [47] suggested that lysophospholipids released from the fat globule membranes by the action of phospholipase act as surface-active agents in the cheese curd, helping emulsification of water and fat during cooking.

\subsubsection{Method of heating}

The type of oven used for baking can have a major impact on cheese performance. Various heating methods, e.g. gas, electric or wood burning ovens are used for pizza and other dishes. For pizza, various types of convection or forced air (fanassisted) ovens are common in food service operations as they give more rapid and even heating than conventional ovens. One popular type is the Impinger ${ }^{\circledR}$ oven where hot air under pressure is forced down on the cheese. This results in rapid heating as the cheese moves through the oven on a conveyor belt. But the jets of hot air also dry out the cheese surface and this oven is more likely to result in blistering and browning of a cheese. The trapped water vapor finds it harder to be released from the surface, which can lead to a bulging up of the cheese. As blisters are formed they are more prone to drying-out, which favors the Maillard reaction and as a result browning is greater in forced-air or Impinger ovens. In conventional ovens, the baking process is slower, which is why forced-air ovens are so popular. For dishes like lasagne, very long cooking times in convection ovens can also lead to more risk of the surface drying-out unless the dish is covered for some of the time. Microwave ovens are often used for quick reheating of foods, including pizza, but they do have the tendency to make the base either brittle or very soft depending on the ingredients used and the cheese itself can get tougher than in a conventional oven. Some frozen pizza suppliers also provide accessories, e.g. a crisping sleeve, to help bake the pizza in a microwave. Depending on the type of oven, the heating temperature and cooking times for pizza and other cheese dishes vary. Regular processed cheese generally have lower melt temperatures than natural cheeses like low moisture part-skim Mozzarella so the heating or baking conditions can be reduced. For applications where process cheeses are subjected to high temperatures (e.g. retorting) then cheeses with restricted melt are used. Sauces or fondues can be readily heated or reheated in a microwave. The food service sector also uses different types of ovens including systems that utilize multiple forms of heating.

Cheese manufacturers provide cheese that can perform as an ingredient under very specific oven types and heating regimes (temperatures and times). Many food service operations use blends of cheese in a variety of dishes and fastfood products. These melts are formulated to consistently deliver the desired flow, stretch, color and flavor. Cheese is shredded, blended, grated and dehydrated and ready for food service operations. Cheese can be individually quick frozen (IQF) after shredding or dicing to provide a convenient and stable (frozen) product for endusers to use on products like pizza, hot 
sandwiches, and Mexican-style dishes. In some situations there can be interactions between the cheese topping and other food ingredients like the sauce on a pizza.

\section{ROLE OF INSOLUBLE CALCIUM ON CHEESE TEXTURE FUNCTIONALITY}

The importance of calcium and phosphate interactions for cheese textural properties has been reviewed $[39,52,53,55]$. It has been recognized for more than 100 years that rate of acid development has a key impact on cheese quality and texture. Cheesemakers later came to recognize that acid development directly influenced the $\mathrm{Ca}$ content of cheese and that the total $\mathrm{Ca}$ content was an important parameter for determining cheese texture [45]. By the late 1980 and early 1990s, there was the realisation that natural rennet-coagulated cheeses, like Cheddar and Emmental, contained a high concentration of insoluble $\mathrm{Ca}[52,63]$. In milk at low $\mathrm{pH}$ values ( $\leq 5.2)$, the CCP is completely dissolved so why does so much of the CCP appear to remain undissolved in cheese? When acid development in cheesemaking occurs in the vat prior to whey drainage, the moisture content of the curd particles is high and the solubility of CCP as a function of $\mathrm{pH}$ is similar to that in milk. When much of the acid development occurs later in the process, e.g. in the hoop or when the curd particles are lower in moisture content it appears to be more difficult to dissolve CCP. This may be the explanation for the key role that the $\mathrm{pH}$ at rennet addition has on the total Ca content of cheese [52]. During the first few weeks after cheese manufacture, and especially in the first few days, there is a decrease in the proportion of insoluble $\mathrm{Ca}$ as a function of the total $\mathrm{Ca}$ content of Cheddar cheese from $\geq 70 \%$ at day 1 to $\sim 60 \%$ after 4 weeks [34]. Shifts in the $\mathrm{Ca}$ equilibrium have been ob- served for several other cheese types, e.g. Mozzarella [28]. If the cheese become very acid, e.g. $\mathrm{pH} \mathrm{4.7,} \mathrm{then} \mathrm{the} \mathrm{insoluble} \mathrm{Ca}$ content of Cheddar decreases during ripening but the levels still remain $\geq 40 \%$ [46]. What limits the extent of the solubilisation of insoluble $\mathrm{Ca}$ in cheese at such low $\mathrm{pH}$ values? It appears that the solubilisation of insoluble $\mathrm{Ca}$ in cheese causes a rapid increase in the serum $\mathrm{Ca}$ content up to some maximum concentration (e.g. [46]). When the Ca content of cheese serum is very high (> $800 \mathrm{mg} \cdot 100 \mathrm{~g}^{-1}$ ) it becomes very susceptible to precipitation of calcium phosphate [65]. This possible mechanism is shown in Figure 1. A lower (maximum) serum $\mathrm{Ca}$ concentration $\left(\sim 700 \mathrm{mg} \cdot 100 \mathrm{~g}^{-1}\right)$ has been reported in very low $\mathrm{pH}$ Cheddar cheeses [46]; presumably the $\mathrm{pH}$ and moisture content of cheese influence the maximum serum $\mathrm{Ca}$ concentration possible before precipitation occurs and therefore further solubilisation of insoluble $\mathrm{Ca}$ is unfavored. O'Mahony et al. [65] were able to increase the total $\mathrm{Ca}$ and insoluble $\mathrm{Ca}$ content of cheese by the incubation of cheese in buffers containing higher serum $\mathrm{Ca}$ concentrations than those present in the serum phase of cheese. Presumably, this was possible because there was a large increase in moisture content of cheeses incubated in these artificial cheese serum buffers. It is now becoming common for cheese researchers, and by some dairy companies, to monitor the insoluble $\mathrm{Ca}$ content of cheese during ripening to gain greater control over cheese functionality.

\section{STRATEGIES TO EXTEND THE PERFORMANCE WINDOW OF CHEESE FUNCTIONALITY}

For ingredient cheeses, like lowmoisture part-skim Mozzarella cheese, there is an initial period where cheese functionality is not suitable, e.g. it may 


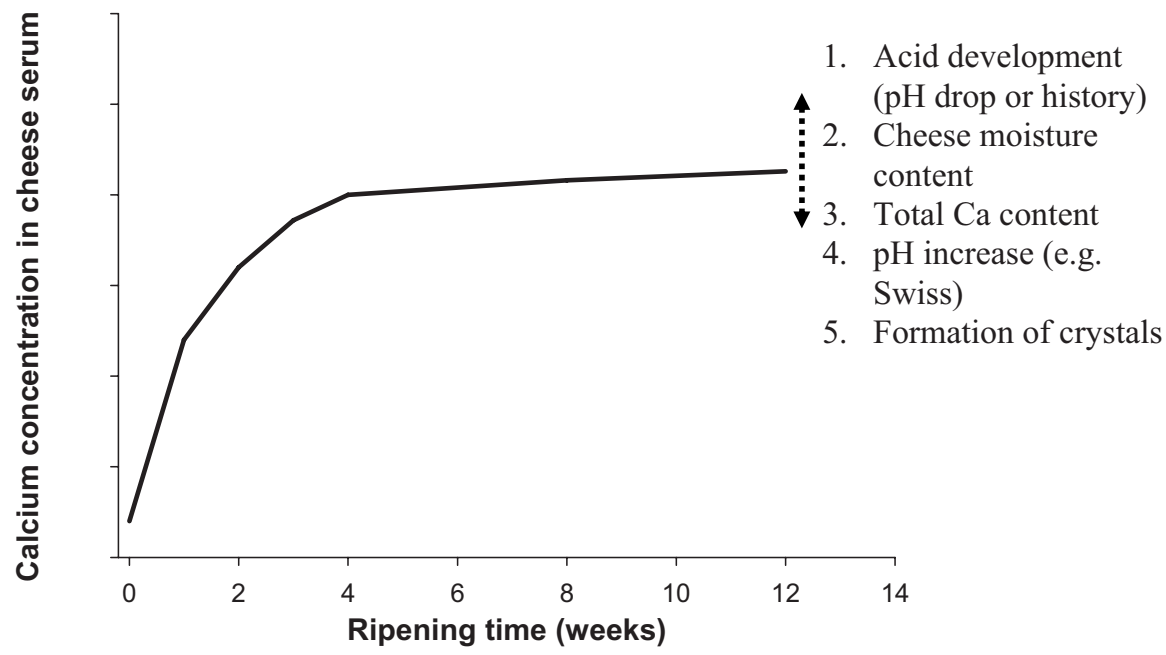

Figure 1. Possible factors affecting the "equilibrium" serum Ca concentration in cheese.

exhibit poor melt or free water. After some ripening period acceptable performance is obtained due to the influence of two reactions (Fig. 2a). Firstly, a shift of some of the insoluble $\mathrm{Ca}$ associated with casein to soluble $\mathrm{Ca}$ in the serum phase $[34,54]$. Secondly, ongoing proteolysis results in the hydrolysis of some bonds on mostly $\alpha_{\mathrm{s}}$-casein, as $\beta$-casein is only slowly hydrolyzed during the ripening of most cheese varieties, e.g. Cheddar. In cooked cheeses plasmin activity becomes more important during ripening due to the denaturation of chymosin [16]. In high cooked cheeses, like Swiss, $\beta$-casein is usually hydrolyzed faster than $\alpha_{\mathrm{s} 1}$-casein [82]. To reduce the extent of proteolysis in Swiss cheese during ripening many cheesemakers now omit Lactobacillus helveticus as a starter culture due to its strong proteolytic activity and instead many use only Lactobacillus delbrueckii subsp. lactis [20].

Recently, O’Mahony et al. [64] added pepstatin (a powerful inhibitor of rennet activity) to whey during Cheddar cheese manufacture in order to inhibit residual rennet activity during cheese ripening.
There was a significant reduction in hardness during the first $21 \mathrm{~d}$ of ripening even in cheese where there was no residual rennet activity. O'Mahony et al. [64] concluded that hydrolysis of $\alpha_{\mathrm{s} 1}$-casein at $\mathrm{Phe}_{23}-\mathrm{Phe}_{24}$ is not a prerequisite for softening of Cheddar cheese during the early stages of ripening. They proposed that this initial softening of texture is principally due to solubilization of some of the CCP associated with the para-casein matrix of the curd.

Many cheese manufacturers would like to be able to extend that acceptable performance period for their cheese to increase the shelf-life of its use as an ingredient and to improve consistency of performance. Ideally, this would produce a cheese where there no biochemical or microbiological activity and where a stable state of $\mathrm{Ca}$ in cheese was achieved immediately after manufacture (Fig. 2b). In many respects a shelf-stable cheese is similar to the characteristics of processed cheese. A summary of some of the various strategies for reducing changes in cheese functionality are given in Table II. 


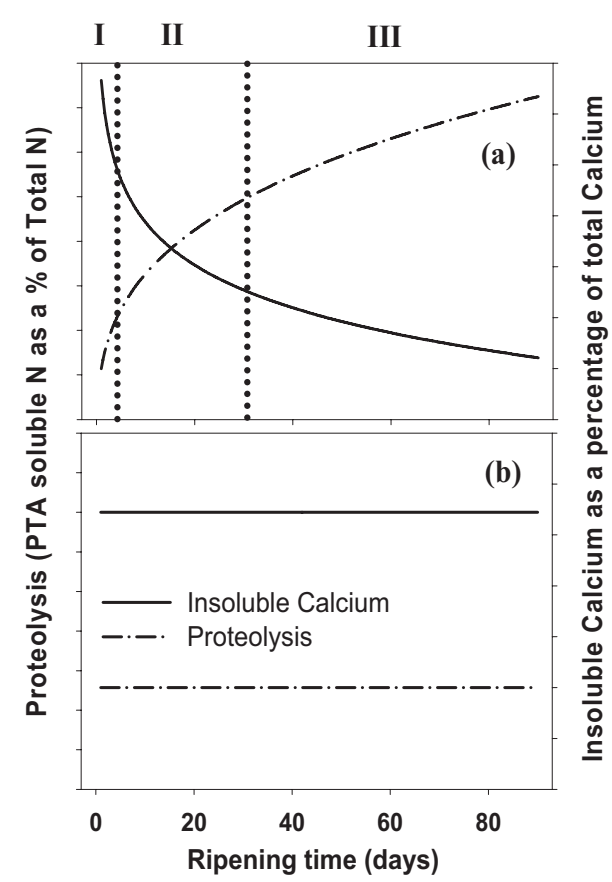

Figure 2. Comparison of ripening changes in a Mozzarella cheese (a) and a shelf stable cheese (b). During cheese ripening there is a reduction in insoluble $\mathrm{Ca}$ content as a $\%$ of total $\mathrm{Ca}(\mathrm{Ca}$ shift) as well as ongoing proteolysis (schematic example only). For a cheese like Mozzarella (a) these changes results in three zones of functional performance: (I) young cheese is tough and has poor melt, (II) acceptable performance window (good melt, stretch and shred), and (III) unacceptable performance window (cheese becomes too soft, soupy and sticky) (modified from [39]).

\subsection{Use of dry dairy ingredients instead of milk}

There are many reasons why cheese manufacturers sometimes use added dairy proteins in cheesemaking: (i) standardize the protein and/or fat content of cheesemilk where skim milk powder, condensed milk/buttermilk, retentates from membrane filtration, or milk protein concentrates may be added (depending on regulations in each country as to what is permitted to be used in a particular cheese variety); (ii) reconstitution of milk for cheesemaking where cheese can be made on-demand (directly from powders when required) [61], powders can be used for cheesemaking in countries where there is little fluid milk and powders can be used to extend existing milk supplies (i.e. make more cheese than what is possible with only local milk); (iii) improve efficiency/increase yield/reduce costs, e.g. use of high concentration factor UF to retain more whey proteins, as a substitute for young cheese (e.g. cheese base) in process cheese, and substitute cheese solids with dairy proteins/powders (e.g. process cheese) [62]; (iv) eliminate the need for a whey separation step [29, 48, 77]; (v) alter functionality: this includes control of melt, increased smoothness of soft cheese, and reduce the amount of ES required for process cheese. Dairy proteins, such as, milk protein concentrates, are also being modified during their manufacture to improve their characteristics in cheese, e.g. modification of their calcium and denatured whey protein contents [8].

\subsection{Process approaches to reduce "ripening" changes}

In Mozzarella, the high curd temperature in the cooker stretcher reduces bacterial numbers and lowers residual enzyme activity during ripening; these process conditions help this high moisture product have good melting functionality over a typical one month refrigerated storage shelf life. Plasmin may remain active as it is more heat-stable that chymosin. Most cheeses will require refrigerated storage prior to use and some will be held frozen. Various strategies for reduce ripening changes in cheese functionality were listed in Table II. Manufacturers can slow down ripening changes, which facilitate 
Table II. Summary of some strategies that have been used to reduce the extent of changes in cheese functionality during storage (extend the performance window).

\begin{tabular}{|c|c|c|}
\hline & $\begin{array}{l}\text { Chemical/Biological } \\
\text { changes targeted }\end{array}$ & Methods/Treatments \\
\hline & Bacterial/enzyme activity & $\begin{array}{l}\text { Heat, } \mathrm{CO}_{2} \text { addition, microfiltration }(\mathrm{MF}) \text {, non- } \\
\text { thermal processes }\end{array}$ \\
\hline \multirow[t]{4}{*}{ Milk } & $\begin{array}{l}\text { Seasonal or milk supply variations } \\
\text { Ratio of proteins/minerals }\end{array}$ & $\begin{array}{l}\text { Reconstitution of cheese milk from dairy pow- } \\
\text { ders or the use of retentates (pre-cheese) }\end{array}$ \\
\hline & $\begin{array}{l}\text { Ratio of total and insoluble } \mathrm{Ca} \text { to } \\
\text { protein }\end{array}$ & $\begin{array}{l}\text { Preacidification, direct acidification, addition } \\
\text { of Ca sequestrant, altered rate of acidification }\end{array}$ \\
\hline & Ratios of individual caseins & $\begin{array}{l}\text { Use of cold MF of cheesemilk to remove some } \\
\text { beta-casein }\end{array}$ \\
\hline & Additional protein crosslinking & $\begin{array}{l}\text { Use of transglutaminase, attachment of dena- } \\
\text { tured whey proteins to caseins }\end{array}$ \\
\hline \multirow[t]{2}{*}{ Curd } & $\begin{array}{l}\text { Ratio of total and insoluble } \mathrm{Ca} \text { to } \\
\text { casein }\end{array}$ & $\begin{array}{l}\text { Preacidification, direct acidification, addition } \\
\text { of Ca sequestrant, altered rate of acidification }\end{array}$ \\
\hline & $\begin{array}{l}\text { Residual rennet, other enzymes } \\
\text { and starter culture activities }\end{array}$ & $\begin{array}{l}\text { Cooking treatment (time and temperature of } \\
\text { curd in the cheese vat or in the mixer/molder) } \\
\text { to denature rennet and other enzymes and re- } \\
\text { duce bacterial numbers, } \\
\text { High salt to inhibit bacterial growth/activity }\end{array}$ \\
\hline \multirow[t]{2}{*}{ Cheese } & $\begin{array}{l}\text { State of } \mathrm{Ca} \text { in cheese (e.g. prevent- } \\
\text { ing solubilization of insoluble } \mathrm{Ca} \\
\text { during ripening) }\end{array}$ & $\begin{array}{l}\text { Addition of Ca sequestrant during cheese man- } \\
\text { ufacture, } \\
\text { Prevent } \mathrm{pH} \text { changes post-manufacture by } \\
\text { washing/diafiltration or using salt sensitive } \\
\text { cultures } \\
\text { High pressure processing }\end{array}$ \\
\hline & $\begin{array}{l}\text { Residual rennet, other enzymes } \\
\text { and starter culture activities }\end{array}$ & $\begin{array}{l}\text { Use of very low storage temperatures, frozen } \\
\text { or individually quick frozen (IQF) cheese } \\
\text { High pressure processing }\end{array}$ \\
\hline \multirow{2}{*}{ Process cheese } & State of $\mathrm{Ca}$ in cheese & Addition of Ca sequestrant \\
\hline & $\begin{array}{l}\text { Residual rennet, other enzymes } \\
\text { and starter culture activities }\end{array}$ & Heating/pasteurization treatment \\
\hline
\end{tabular}

shipment of their cheese over long distances, e.g. overseas. Slowing ripening changes in natural cheese could be helpful to the manufacturers of processed cheese as they require young cheese with a high level of intact casein in their formulations (e.g. slices), and during ripening the intact casein content of natural cheese declines [40].

High pressure processing (HPP) $(>400 \mathrm{MPa})$ of cheese curd has been applied to reduce proteolysis during ripening [10]. HPP has been used to improve the meltability of young Mozzarella cheese [40]. It is known that high pressure processing solubilises some of the insoluble $\mathrm{Ca}$ in milk but most of this change is restored during subsequent storage (after pressure release) of HPP-treated milk [21, 36]. It is not clear what the impact of HPP is on the insoluble $\mathrm{Ca}$ fraction in cheese. The impact of HPP on cheese properties has been reviewed [51]. Moderate (345 MPa) to HPP of 1 -d old 
Cheddar cheese curd has been reported to improve the shredding properties, which could allow earlier shredding of this milled curd cheese [76].

\subsection{Blurring the lines between natural and process cheese}

There have been a number of reports where ES have been added to "natural" cheese in order to modify cheese functionality [4-6, 56, 60, 68]. Emulsifying salts are not listed as optional ingredients in most current standards of identity for various cheese varieties (including Mozzarella), so other terms like pasta-filata type cheese or pizza cheese are used to describe these cheeses. The ES are sometimes added into the starter culture media, or with the (dry) salt or in a cooker for cheeses like Mozzarella. The growth in waterless or dry cookers for Mozzarella cheese [13], which are more like process cheese operations, has made it easier to incorporate these ingredients without concerns for losses into the cooker water. In recombined cheeses or analogue cheeses, ES are often added to help hydrate milk ingredients and improve their ability to emulsify the added fat. The use of ES offers the potential for greater consistency of cheese performance by controlling the state of $\mathrm{Ca}$ in cheese and avoiding the ongoing solubilisation of insoluble $\mathrm{Ca}$ that occurs during the ripening of natural cheese. Traditional processed cheeses do not perform as well as Mozzarella cheese for pizza type applications since the milkfat is completely emulsified in process cheese and the release of fat during baking is considered to reduce scorching. Processed cheeses are usually not stringy. So a "partially processed" but still "natural" cheese has some advantages, especially for the use of these cheeses as ingredients in various foods where standards of identity are often less important than for retail cheese. A greater range of cheese types (e.g. Feta, Blue, Cream cheese) are now also being subjected to processing in addition to the commonly used ingredient cheese, like Cheddar and Emmental. During processing flavors or condiments can be added and processing also facilitates a modification in the original cheese texture.

\section{CREAM CHEESE AS AN INGREDIENT IN FOODS}

Cream cheese includes several closelyrelated products including single Cream cheese, double Cream cheese, Neufchâtel (spelled Neufchatel in the US) and Bakers' cheese [26]. Cheeses that are closely related to Cream cheese are produced in other countries. In the US standards of identity, Cream cheese must contain a minimum of $33 \%$ fat and a maximum of $55 \%$ moisture. Cream cheese is made from milk containing $8-14 \%$ fat (commercially milk with higher total solids is often used by reduce the volume of acid whey produced at the separation step). Milk is standardized and homogenized (e.g., 12-17 MPa at $50{ }^{\circ} \mathrm{C}$ ) and cooled to temperatures between $31-22{ }^{\circ} \mathrm{C}$ for incubation. Whey is separated from hot curd and the curd is salted, stabilizers are usually added to reduce whey separation during storage and the product is packaged.

Cream cheese is another example of an ingredient cheese as it is mainly used as an ingredient in spreads, spread on bagels and as an ingredient in (baked) cheesecakes. During heating, cream cheese exhibits markedly different rheological behaviour compared to natural cheeses (Fig. 3). In most natural, rennet-coagulated cheeses (e.g. Colby) the storage modulus (stiffness) decreases with increasing temperature during heating from 5 to $\sim 70{ }^{\circ} \mathrm{C}$. In contrast, cream cheese exhibits a decrease between 5 and $\sim 40{ }^{\circ} \mathrm{C}$ and thereafter only a slight decrease in the storage modulus is observed. The loss tangent (ratio of viscous 


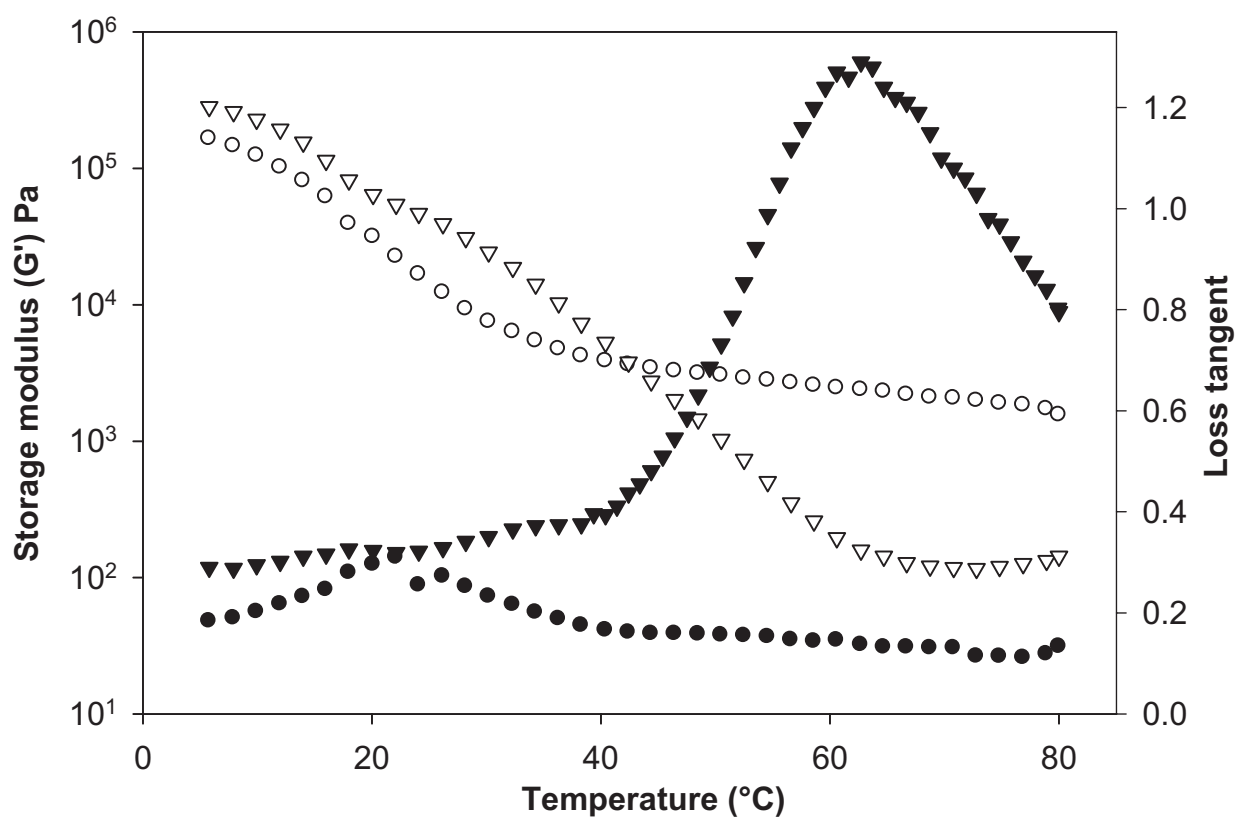

Figure 3. Rheological properties of Colby $(\boldsymbol{\nabla}, \nabla)$ and cream cheese $(\bullet, \circ)$ during heating from 5 to $80{ }^{\circ} \mathrm{C}$. Open and full symbols represent storage modulus and loss tangent, respectively. Colby cheese was aged for one month. Test conditions were a maximum strain of $0.2 \%$ and a constant frequency of $0.1 \mathrm{~Hz}$.

to elastic modulus) profile during heating is also very different in cream cheese with only a minor peak observed between 20-30 ${ }^{\circ} \mathrm{C}$ compared to the large loss tangent peak observed between $60-70{ }^{\circ} \mathrm{C}$ in rennet-coagulated cheeses (Fig. 3). It should be mentioned that cream cheese is a low protein (e.g. $8 \%$ ), high moisture $(55 \%)$ product. It is likely that in a low $\mathrm{pH}$, acidcoagulated product, like cream cheese, there is a lot of electrostatic attraction between oppositely charged proteins as well as hydrophobic interactions. These attractive forces are sufficient to hinder softening and melt at high temperatures [53]. Cream cheese is often used as a major ingredient in baked cheesecakes where softening during heating is important but melt is undesirable. We have observed that there is significant correlation $\left(\mathrm{R}^{2}=0.7\right)$ between the texture properties of different commercial samples of cream cheese and the firmness of cheesecake made with these cream cheeses (Fig. 4) (unpublished data from Brighenti, Govindasamy-Lucey, Lim, Nelson, and Lucey). This again highlights the importance of controlling cheese functionality as the cheese can directly influence the properties of foods where it is an ingredient. Figure 4 indicates that firmer, less spreadable cream cheese produces cheesecakes that are firmer.

\section{CONCLUDING REMARKS}

Cheese continues to be a popular ingredient in a wide range of foods and dishes. The ability of cheesemakers to be able to produce cheese that has the very specific performance characteristics required in these foods is critical for the continued 


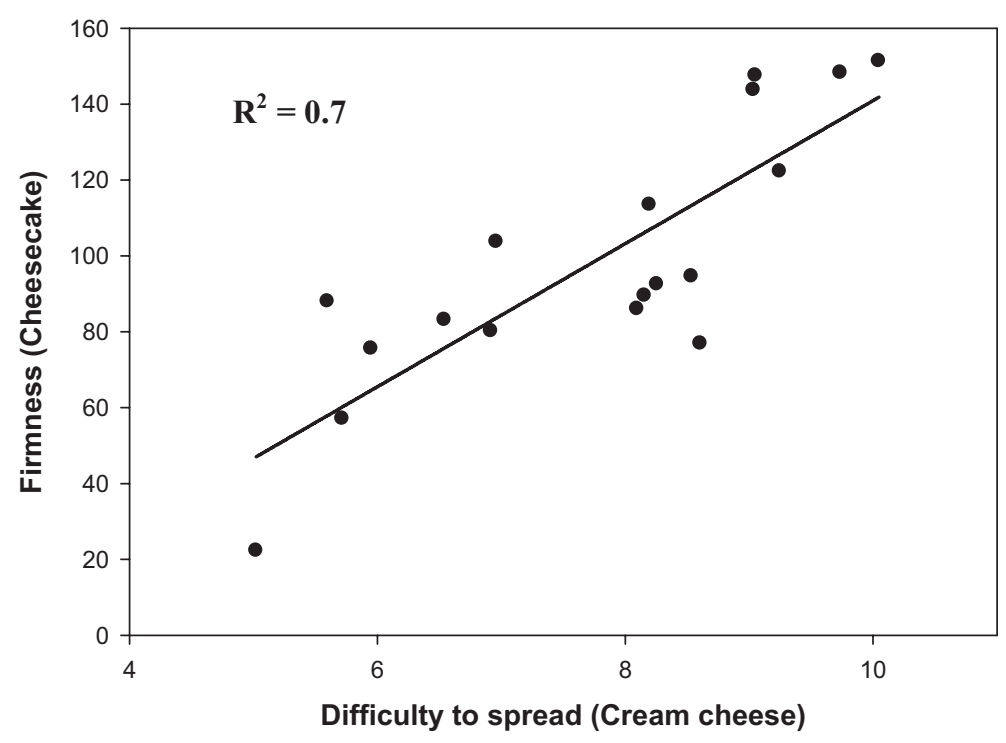

Figure 4. Comparison of the firmness of cheesecakes (as determined by a penetration test) (units are in grams force) with the difficulty to spread of cream cheese (as determined by quantitative sensory analysis, anchored scale from 1-15) used as an ingredient in the cheesecakes. The cream cheeses were commercial samples with a range of fat contents (unpublished data from Brighenti, Govindasamy-Lucey, Lim, Nelson, and Lucey).

growth in the use of cheese by the food industry. Once a cheesemaking method has been devised to produce a cheese with the required performance characteristics, many cheesemakers would like to be able to extend the ripening period where the cheese exhibits these desirable properties. This has resulted in a blurring of divisions between natural and processed cheese, the use of recombined dairy ingredients to manufacture cheese on-demand and techniques to restrict ripening changes. This new paradigm is changing the cheese industry but the key to this type of approach is a molecular based understanding of what controls cheese texture and functionality. One such model has recently been described [53] and is currently being applied to help explain cheese properties $[39,81]$ and ultimately this approach should help to predict new or improved functional performances for cheese. Approaches from polymer science are also being tested for their applicability to model and explain the rheological behaviour of cheese [81]. When a cheese is being made specifically for processing it is unclear why it would be required (e.g., by regulations) to have all the attributes of a table cheese, e.g. in a Swiss cheese for processing why would the size and distribution of eyes be an important quality attribute?

Many challenges remain including a more rigorous understanding of the molecular interactions that determine cheese functional attributes. The development of low or nonfat cheese with functional performance (including flavor) approaching the full fat version is another challenge for cheese researchers that is hindered by our lack of a detailed understanding of how to control the molecular interactions between the caseins in cheese as well the biochemistry or flavor development. 
Most detailed studies of cheese functionality have been performed on a few varieties (e.g. Cheddar, Mozzarella and Emmental) while a growing range of cheese varieties are being used industrially as food ingredients. In the future a greater understanding and characterization of the functional properties of these other cheese varieties is needed. That future work will reveal if the assertions discussed in this article, which were primarily derived from the study of cheeses like Cheddar and Mozzarella, are valid for other cheese types. Developing a consistent and authentic flavor in ingredient cheeses (e.g. Cheddar) within a short aging period also remains a challenge. Enzyme-modified cheeses, exogenous enzymes, heat-shocked or attenuated cultures, or adjunct bacteria are used to assist with flavor generation in some types of ingredient cheeses (e.g. processed cheese or cheese powders). There is also a growing trend of adding other non-dairy ingredients (e.g. hydrocolloids, nutraceutricals) to cheeses and the impact of these materials on cheese texture, functionality and flavor is not well understood.

Acknowledgements: The author wants to acknowledge the contribution of K. Nelson (Wisconsin Center for Dairy Research) for valuable help with Table I (uses of cheese in various foods). The author also appreciates the many discussions and collaborations on this topic with M.E. Johnson and D.S. Horne. The author also wants to acknowledge the support for this work by the Wisconsin Milk Marketing Board and Dairy Management Inc.

\section{REFERENCES}

[1] Adamberg K., Antonsson M., Vogensen F.K., Nielsen E.W., Kask S., Møller P.L., Ardö Y., Fermentation of carbohydrates from cheese sources by non-starter lactic acid bacteria isolated from semi-hard Danish cheese, Int. Dairy J. 15 (2005) 873-882.

[2] Auty M.A., Guinee T.P., Mullins C., Mulvihill D.M., Dynamic confocal scanning laser microscopy methods for studying milk protein gelation and cheese melting, Scanning 21 (1999) 299-304.

[3] Awad S., Hassan A.N., Halaweish F., Application of exopolysaccharide-producing cultures in reduced-fat Cheddar cheese: Composition and proteolysis, J. Dairy Sci. 88 (2005) 4195-4203.

[4] Barz R.L., Cremer C.P., Process of making acceptable Mozzarella cheese without aging, US Pat. No. 5200 216, Leprino Foods Company, assignee, 1993.

[5] Barz R.L., Cremer C.P., Process of making Mozzarella cheese, US Pat. No. 5567 464, Leprino Foods Company, assignee, 1996.

[6] Barz R.L., Cremer C.P., Durkin A.V., Process of making a soft or semi-soft fibrous cheese, US Pat. No. 5902 625, Leprino Foods Company, assignee, 1999.

[7] Bednarski W., Hammond E.G., Selection of Lactobacillus mutants for their $\alpha$-dicarbonyl production, J. Dairy Sci. 73 (1990) 14501453.

[8] Bhaskar G.V., Havea P., Elson P., Dairy protein process and applications thereof, PCT Pat. No. WO 2004 057971, 2004.

[9] Briad V., Leconte N., Michel F., Michalski M.C., The fatty acid composition of small and large naturally occurring milk fat globules, Eur. J. Lipid Technol. 105 (2003) 677682.

[10] Carroll T., Honore C., Crow V., White N., Chen P., Johnston K., Dairy product and process, PCT Pat. No. WO 2004 045295, 2004.

[11] Childs J.L., Daubert C.R., Stefanski L., Foegeding E.A., Factors regulating cheese shreddability, J. Dairy Sci. 90 (2007) 21632174.

[12] Dabour N., Kheadr E.E., Fliss I., LaPointe G., Impact of ropy and capsular exopolysaccharide-producing strains of Lactococcus lactis subsp. cremoris on reduced-fat Cheddar cheese production and whey composition, Int. Dairy J. 15 (2005) 459-471.

[13] Dahlstrom D.G., Wiegand J., Aimutis W.R., Pasta filata cheese, US Pat. No. 6319 526, 2001.

[14] Everett D.W., Rowney M.K., Hickey M.W., Roupas P., Salt-induced structural changes in Mozzarella cheese and the impact upon free oil formation in ripening cheese, Lait 84 (2004) 539-549.

[15] Farnworth E.R., Champagne C.P., van Calsteren M.R., Exopolysaccharides 
from lactic acid bacteria: food uses, production, chemical structures and health benefits, in: Wildman R.E.C. (Ed.), Handbook of Nutraceuticals and Functional Foods, 2nd edn., CRC Press, Boca Raton, 2006, pp. 353-371.

[16] Faryke N.Y., Fox P.F., Observations on plasmin activity in cheese, J. Dairy Res. 57 (1990) 413-418.

[17] Fife R.L., McMahon D.J., Oberg C.J., Functionality of low fat Mozzarella cheese, J. Dairy Sci. 79 (1996) 1903-1910.

[18] Foegeding E.A., Brown J., Drake M.A., Daubert C.R., Sensory and mechanical aspects of cheese texture, Int. Dairy J. 13 (2003) 585-591.

[19] Foegeding E.A., Drake M.A., Sensory and mechanical properties of cheese texture, J. Dairy Sci. 90 (2007) 1611-1624.

[20] Fröhlich-Wyder M.T., Bachmann H.P., Cheeses with propionic acid fermentation, in: Fox P.F., McSweeney P.L.H., Cogan T.M., Guinee T.P. (Eds.), Cheese: Chemistry, Physics and Microbiology, Vol. 2, 3rd edn., Academic Press, London, UK, 2004, pp. 141-156.

[21] Gaucheron F., Famelart M.H., Mariette F., Raulot K., Michel F., Le Graet Y., Combined effects of temperature and high-pressure treatments on physicochemical characteristics of skim milk, Food Chem. 59 (1997) 439-447.

[22] Govindasamy-Lucey S., Lin T., Jaeggi J.J., Johnson M.E., Lucey J.A., Influence of condensed sweet cream buttermilk on the manufacture, yield, and functionality of pizza cheese, J. Dairy Sci. 89 (2006) 454-467.

[23] Guinee T.P., The functionality of cheese as an ingredient: a review, Aust. J. Dairy Technol. 57 (2002) 79-91.

[24] Guinee T.P., Auty M.A.E., Mullins C., Observations on the microstructure and heatinduced changes in the viscoelasticity of commercial cheeses, Aust. J. Dairy Technol. 54 (1999) 84-89.

[25] Guinee T.P., Kilcawley K.N., Cheese as an ingredient, in: Fox P.F., McSweeney P.L.H., Cogan T.M., Guinee T.P. (Eds.), Cheese: Chemistry, Physics and Microbiology, Vol. 2, 3rd edn., Academic Press, London, UK, 2004, pp. 394-428.

[26] Guinee T.P., Pudja P.D., Farkye N.Y., Fresh acid-curd cheese varieties, in: Fox P.F. (Ed.), Cheese: Chemistry, Physics and Microbiology, Vol. 1, 2nd edn., Chapman \& Hall, London, UK, 1993, pp. 363-419.
[27] Gunasekaran S., Ak M.M., Cheese rheology and texture, CRC Press, New York, 2003.

[28] Guo M.R., Kindstedt P.S., Age related changes in the water phase of Mozzarella cheese, J. Dairy Sci. 78 (1995) 2099-2107.

[29] Han X.-Q., Process for making cream cheese without whey separation, US Pat. No. 6406 736, 2002.

[30] Han X.-Q., Damodaran S., Thermodynamic compatability of substrate proteins affects their cross-linking by transglutaminase, J. Agric. Food Chem. 44 (1996) 1211-1217.

[31] Han X.-Q., Pfeifer J.K., Lincourt R.H., Process for making a wheyless cream cheese using transglutaminase, US Patent No. 6416 797, 2002.

[32] Hassan A.N., Possibilities and challenges of exopolysaccharide-producing lactic cultures in dairy foods, J. Dairy Sci. 91 (2008) 12821298.

[33] Hassan A.N., Awad S., Application of exopolysaccharide-producing cultures in reduced-fat Cheddar cheese: Cryo-scanning electron microscopy observations, J. Dairy Sci. 88 (2005) 4214-4220.

[34] Hassan A., Johnson M.E., Lucey J.A., Changes in the proportions of soluble and insoluble calcium during ripening of Cheddar cheese, J. Dairy Sci. 87 (2004) 854862.

[35] Horne D.S., Casein interactions: Casting light on the black boxes, the structure in dairy products, Int. Dairy J. 8 (1998) 171177.

[36] Huppertz T., Fox P.F., Kelly A.L., High pressure-induced changes in ovine milk. 1. Effects on the mineral balance and $\mathrm{pH}$, Milchwissenschaft 61 (2006) 285-288.

[37] Jana A.H., Upadhyay K.G., Homogenisation of milk for cheesemaking - a review, Aust. J. Dairy Technol. 47 (1992) 72-79.

[38] Jaros D., Partschefeld C., Henle T., Rohm H., Transglutaminase in dairy products: chemistry, physics, applications, J. Text. Stud. 37 (2006) 113-155.

[39] Johnson M.E., Lucey J.A., Calcium: A key factor in controlling cheese functionality, Aust. J. Dairy Technol. 61 (2006) 147-153.

[40] Johnston D.E., Darcy P.C., The effects of high pressure treatment on immature Mozzarella cheese, Milchwissenschaft 55 (2000) 617-620.

[41] Keller B., Olson N.F., Richardson T., Mineral retention and rheological properties 
of Mozzarella cheese made by direct acidification, J. Dairy Sci. 57 (1974) 174-180.

[42] Kindstedt P.S., Functional properties of Mozzarella cheese on pizza: A review, Cult. Dairy Prod. J. 26 (1991) 27-31.

[43] Kindstedt P.S., Effect of manufacturing factors, composition, and proteolysis on the functional characteristics of Mozzarella cheese, Crit. Rev. Food Sci. Nutr. 33 (1993) 167-187.

[44] Kindstedt P.S., Caric M., Milanovic S., Pasta-filata cheeses, in: Fox P.F., McSweeney P.L.H., Cogan T.M., Guinee T.P. (Eds.), Cheese: Chemistry, Physics and Microbiology, Vol. 2, 3rd edn., Academic Press, London, UK, 2004, pp. 251-277.

[45] Lawrence R.C., Gilles J., Creamer L.K., The relationship between cheese texture and flavour, N. Z. J. Dairy Sci. Technol. 18 (1983) 175-190.

[46] Lee M.-R., Johnson M.E., Lucey J.A., Impact of modifications in acid development on the insoluble $\mathrm{Ca}$ content and rheological properties of Cheddar cheese, J. Dairy Sci. 88 (2005) 3798-3809.

[47] Lilbaek H.M., Broe M.L., Høier E., Fatum T.M., Ipsen R., Sørensen N.K., Improving the yield of Mozzarella cheese by phospholipase treatment of milk, J. Dairy Sci. 89 (2006) 4114-4125.

[48] Lincourt R.H., Clarkson A.C., Wheyless process for production of string cheese, WIPO Pat. No. WO/2006/031694, 2006.

[49] Lopez C., Focus on the supramolecular structure of milk fat in dairy products, Reprod. Nutr. Dev. 45 (2005) 497-511.

[50] Lopez C., Camier B., Gassi J.Y., Development of the milk fat microstructure during the manufacture and ripening of Emmental cheese observed by confocal laser scanning microscopy, Int. Dairy J. 17 (2007) 235-247.

[51] López-Fandiño R., High pressure-induced changes in milk proteins and possible applications in dairy technology, Int. Dairy J. 16 (2006) 1119-1131.

[52] Lucey J.A., Fox P.F., Importance of calcium and phosphate in cheese manufacture: A review, J. Dairy Sci. 76 (1993) 1714-1724.

[53] Lucey J.A., Johnson M.E., Horne D.S., Perspectives on the basis of the rheology and texture properties of cheese, J. Dairy Sci. 86 (2003) 2725-2743.

[54] Lucey J.A., Mishra R., Hassan A., Johnson M.E., Rheological and calcium equilibrium changes during ripening of Cheddar cheese, Int. Dairy J. 15 (2005) 645-653.

[55] McMahon D.J., Oberg C.J., Role of calcium and sodium in functionality of Mozzarella cheese, in: Proceedings 35th Annual Marschall Italian \& Specialty Cheese Seminar, Sept. 16-17, Madison, WI, USA, 1998, pp. 1-9.

[56] Merrill R.K., Anderson T.L., Process of making a homogeneous cheese, US Pat. No. 7291 356, 2007.

[57] Metzger L.E., Mistry V.V., A new approach using homogenization of cream in the manufacture of reduced fat Cheddar cheese. 1. Manufacture, composition, and yield, J. Dairy Sci. 77 (1994) 3506-3515.

[58] Michalski M.C., Camier B., Briad V., Leconte N., Gassi J.Y., Goudédranche H., Michel F., Fauquant J., The size of native milk fat globules affects the physico-chemical and functional properties of Emmental cheese, Lait 84 (2004) 343358

[59] Michalski M.C., Gassi J.Y., Famelart M.H., Leconte N., Camier B., Michel F., Briad V., The size of native milk fat globules affects physico-chemical and sensory properties of Camembert cheese, Lait 83 (2003) 131-143.

[60] Mizuno R., Lucey J., Effects of two types of emulsifying salts on the functionality of non-fat pasta filata cheese, J. Dairy Sci. 88 (2005) 3411-3425.

[61] Moran J.W., Dever H.A., Miller A.M., Silver R.S., Hyde M.A., Continuous on-demand manufacture of process cheese, US Pat. No. 6183 804, 2001.

[62] Moran J.W., Trecker G.W., Monckton S.P., Continuous manufacture of process cheese, US Pat. No. 6183 805, 2001.

[63] Morris H.A., Holt C., Brooker B.E., Banks J.M., Manson W., Inorganic constituents of cheese: analysis of juice from one-month old Cheddar cheese and the use of light and electron microscopy to characterize the crystalline phases, J. Dairy Res. 55 (1988) 255268.

[64] O’Mahony J.A., Lucey J.A., McSweeney P.L.H., Chymosin-mediated proteolysis, calcium solubilization, and texture development during the ripening of Cheddar cheese, J. Dairy Sci. 88 (2005) 3101-3114.

[65] O’Mahony J.A., McSweeney P.L.H., Lucey J.A., A model system for studying the effects of colloidal calcium phosphate concentration on the rheological properties of Cheddar cheese, J. Dairy Sci. 89 (2006) 892-904. 
[66] O’Mahony J.A., McSweeney P.L.H., Lucey J.A., Observations on the rheological and functional properties of model cheeses made using milk protein concentrate solutions with different ratios of $\alpha_{\mathrm{s} 1}$-: $\beta$-casein, Milchwissenschaft 63 (2008) 145-148.

[67] Nielsen P.M., Process for producing cheese, US Pat. No. 6551 635, 2003.

[68] Pastorino J., Hansen C.L., McMahon D.J., Effect of sodium citrate on structure-function relationships of Cheddar cheese, J. Dairy Sci. 86 (2003) 3113-3121.

[69] Perry D.B., McMahon D.J., Oberg C.J., Effect of exopolysaccharide-producing cultures on moisture retention in low fat Mozzarella cheese, J. Dairy Sci. 80 (1997) 799-805.

[70] Petersen B.L., Dave R.I., McMahon D.J., Oberg C.J., Broadbent J.R., Influence of capsular and ropy exopolysaccharide-producing Streptococcus thermophilus on Mozzarella cheese and cheese whey, J. Dairy Sci. 83 (2000) 1952-1956.

[71] Reparet J.-M., Noël Y., Relation between a temperature-sweep dynamic shear test and functional properties of cheeses, Lait 83 (2003) 321-333.

[72] Reps A., Hammond E.G., Glatz B.A., Carbonyl compounds produced by the growth of Lactobacillus bulgaricus, J. Dairy Sci. (1987) 559-562.

[73] Rowney M., Hickey M.W., Roupas P., Everett D.W., Factors affecting the functionality of Mozzarella cheese, Aust. J. Dairy Technol. 54 (1999) 94-102.

[74] Rowney M., Hickey M.W., Roupas P., Everett D.W., The effect of homogenization and milk fat fractions on the functionality of Mozzarella cheese, J. Dairy Sci. 86 (2003) 712-718.

[75] Rudan M.A., Barbano D.M., A model of Mozzarella cheese melting and browning during pizza baking, J. Dairy Sci. 81 (1998) 2312-2319.

[76] Serrano J., Velazquez G., Lopetcharat K., Ramirez J.A., Torres J.A., Moderately high hydrostatic pressure processing to reduce production costs of shredded cheese: microstructure, texture, and sensory properties of shredded milled curd Cheddar, J. Food Sci. 70 (2005) 286-293.

[77] Silver R.S., Han X.-Q., Lincourt R., Cardona M.L., Wheyless process for production of natural Mozzarella cheese, US Pat. No. 6372 268, 2002.

[78] Soe J.B., Petersen L.W., Method of reducing or preventing Maillard reactions in potato with hexose oxidase, Danisco A/S, assignee, US Pat. No. 6872 412, 2005.

[79] Thornalley P.J., Dicarbonyl intermediates in the Maillard reaction, Ann. N. Y. Acad. Sci. 1043 (2005) 111-117.

[80] Tuinier R., ten Grotenhuis E., Holt C., Timmins P.A., de Kruif C.G., Depletion interaction of casein micelles and an exocellular polysaccharide, Phys. Rev. E 60 (1999) 848-856.

[81] Udayarajan C., Lucey J.A., Horne D.S., Use of time-temperature superposition to study the rheological properties of cheese during heating and cooling, Int. J. Food Sci. Technol. 42 (2007) 686-698.

[82] Upadhyay V.K., McSweeney P.L.H., Magboul A.A.A., Fox P.F., Proteolysis in cheese during ripening, in: Fox P.F., McSweeney P.L.H., Cogan T.M., Guinee T.P. (Eds.), Cheese: Chemistry, Physics and Microbiology, Vol. 1, 3rd edn., Academic Press, London, UK, 2004, pp. 391-433.

[83] Walstra P., Relation between structure and texture of cultured milk products, in: Texture of Fermented Milk Products and Dairy Desserts, Special Issue 9802, Int. Dairy Fed., Brussels, Belgium, 1998, pp. 9-15.

[84] Welman A.D., Maddox I.S., Exopolysaccharides from lactic acid bacteria: perspectives and challenges, Trends Biotechnol. 21 (2003) 269-274.

[85] Yee J.J., Hunt C., Processed cheese with improved firmness using cross-linking enzymes, US Pat. No. 7267 831, 2007. 